\title{
Two-millimeter dermoscopically detected excision margins in the treatment of basal cell carcinoma: an assessment of radicality and recurrence
}

\author{
Pierfranco Simone, Carlo Carusi, Riccardo lannuzzi, Paolo Persichetti \\ Division of Plastic and Reconstructive Surgery, Campus Bio-Medico University, 00128 Rome, Italy. \\ Corresponding Author: Dr. Pierfranco Simone, Division of Plastic and Reconstructive Surgery, Campus Bio-Medico University, Via \\ Alvaro del Portillo 200, 00128 Rome, Italy. E-mail: p.simone@unicampus.it
}

Sir,

Eighty-five percent of all basal cell carcinomas (BCCs) are located in the head and neck, with a markedly increased incidence after the age of 40 years. Complete extirpation in the early phase allows to limit skin excision and facilitates reconstruction, reducing consequent scarring. In the medical literature, it is reported that appropriate excision margins should be included between 3 and $10 \mathrm{~mm}$, based on location, dimensions, margins and histology ${ }^{[1]}$ BCC margins are defined by the discontinuation of well-known dermoscopic features along the skin lesion borders, so separating cancer from healthy skin. ${ }^{[2]}$ The authors conducted a study to assess the effectiveness of preoperative dermoscopic evaluation of BCC peripheral margins, in order to achieve complete excision.

Fifty-seven patients presenting BCC in the head and neck areas were operated on, from February 2012 to June 2012, at the Department of Plastic and Reconstructive Surgery of the Campus Bio-Medico University, Rome, Italy. Morphea-type, recurrent and superficial multifocal BCC were not included in the study. In all cases, margins were identified with a polarized-light dermoscope, at 30-fold magnification (Videocap ${ }^{\circledR}$, Video Loupe VL-7EXII). A 0.5 -mm tip skin marker was used to draw incision lines, $2 \mathrm{~mm}$ off the dermoscopically detected borders [Figure 1]. The contact

\begin{tabular}{|l|l|}
\hline \multicolumn{2}{|c|}{ Access this article online } \\
\hline Quick Response Code: & Website: \\
\hline & http://www.parjournal.net \\
\cline { 2 - 3 } & \\
\hline
\end{tabular}

plate was applied to the skin with little pressure, to avoid blanching of vessels. The study protocol and procedures met the ethical standards of the committee on human experimentation and with the Helsinki Declaration of 1975, as revised in 1983.

Excised skin lesions varied from 4 to $15 \mathrm{~mm}$ in maximum diameter. The histology report showed: nodular 25 cases (43.9\%), infiltrating 2 cases (3.5\%), superficial 30 cases (52.6\%). In all patients, tumours resulted as being totally excised after histological evaluation. Moreover, at follow-up visits, between 12 and 36 months postoperatively, no recurrence was detected. In terms of lesion dimensions, clinical and dermoscopic assessment corresponded. In 12 cases (21\%), borders were apparently well-defined, but dermoscopy showed larger extension, with histologically confirmed excision margins.

Reduced excision margins allowed preservation of healthy tissue, which consented ellipse excision and direct wound closure in most cases. This reflects in better aesthetic results, particularly noteworthy in the facial area. ${ }^{[3]}$

Less invasive reconstructive procedures, fewer secondary surgeries for reoperation imply reduced costs. Preoperative

This is an open access article distributed under the terms of the Creative Commons Attribution-NonCommercial-ShareAlike 3.0 License, which allows others to remix, tweak and build upon the work non-commercially, as long as the author is credited and the new creations are licensed under the identical terms.

For reprints contact: service@oaepublish.com

How to cite this article: Simone $P$, Carusi C, Iannuzzi R, Persichetti P. Two-millimeter dermoscopically detected excision margins in the treatment of basal cell carcinoma: an assessment of radicality and recurrence. Plast Aesthet Res 2016;3:269-70.

Received: 01-07-2016; Accepted: 08-07-2016 


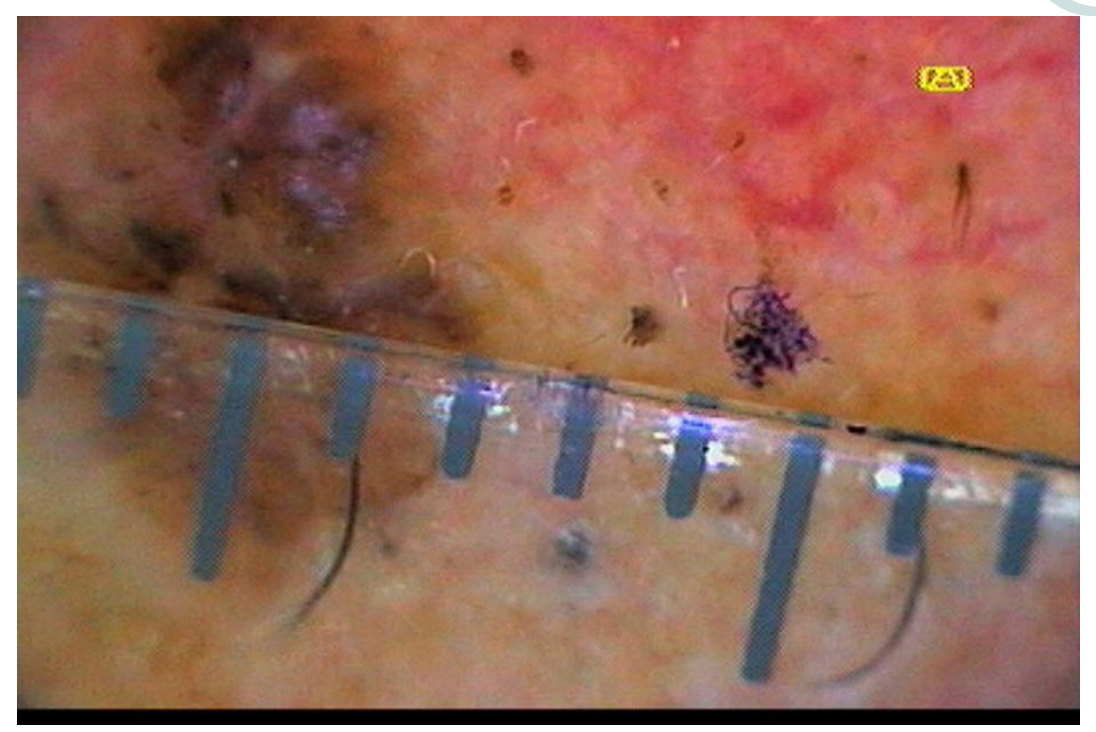

Figure 1: Two-millimeter excision margins in a case of a nodular basal cell carcinoma on the nasal dorsum

dermoscopy is quick, straightforward and less expensive than Mohs surgery.

It is evident that an adequate dermoscopic assessment can be performed in every surgical setting, with a portable device. ${ }^{[4]}$

Our study showed that, following a 2-mm margin excision, no recurrence was observed after a 36-month follow-up period, in contradistinction to the data reported in the medical literature $(3.96 \%) .^{[5]}$

We believe that a thorough dermoscopic detection of tumour borders contributes significantly to the identification of safe BCC excision margins.

\section{Financial support and sponsorship} Nil.

\section{Conflicts of interest}

There are no conflicts of interest.

\section{REFERENCES}

I. Sterry W; European Dermatology Forum Guideline Committee. Guidelines: the management of basal cell carcinoma. Eur J Dermatol 2006; 16:467-75.

2. Giacomel J, Zalaudek I. Dermoscopy of superficial basal cell carcinoma Dermatol Surg 2005;31:1710-3.

3. Caresana G, Giardini R. Dermoscopy-guided surgery in basal cell carcinoma. J Eur Acad Dermatol Venereol 20 I0;24:I395-9.

4. Carducci M, Bozzetti M, Foscolo AM, Betti R. Margin detection using digital dermatoscopy improves the performance of traditional surgical excision of basal cell carcinomas of the head and neck. Dermatol Surg 201 I;37:280-5.

5. Gulleth Y, Goldberg N, Silverman RP, Gastman BR. What is the best surgical margin for a Basal cell carcinoma: a meta-analysis of the literature. Plast Reconstr Surg 2010; 126:1222-31. 